\title{
Analysis of Logistic Strategy based on SWOT and AHP Methods
}

\author{
Xuefeng Wang \\ Research Center of Logistics, \\ Shanghai Maritime University, \\ Shanghai, 201306, China \\ wangxf@shmtu.edu.cn
}

\author{
Pengcheng $\mathrm{Wu}^{*}$ \\ Shanghai International Shipping \\ Service Center Development Co. Ltd, \\ Shanghai, 201306, China \\ shgjhyfwzx@126.com,
}

\author{
Tianrong Huang \\ Shanghai Urban Construction \\ Development Institute (group) Co. Ltd, \\ Shanghai, 200125, China \\ study_2016@126.com
}

\begin{abstract}
The SWOT (Strengths-Weaknesses-Opportunities and Threats) was very classic qualitative analysis methods in al fields; And the AHP (analytic hierarchy process) was quite practical in quantitative analysis. Through cooperating SWOT analysis and AHP (analytic hierarchy process), a complete qualitative and quantitative analysis framework was constituted. And this model was applied to analyze the major logistical strategy factors in Guangzhou port in an explicit way. It has been revealed that the most important factors for Guangzhou port was superior geographic location, poor natural condition, hinterland economic development and strength opponent. And then the optimized logistic strategy was proposed and determined. And the option of logistical strategy in Guangzhou port should be conservative, which means the advantages of Guangzhou port was smaller than the disadvantages, and its development should overcome the difficulties. This innovated framework was proved to be feasible to conduct similar analysis. And it is very useful in future and should serve as reference guide for similar analysis.
\end{abstract}

Keywords—SWOT analysis, analytic hierarchy process, logistic strategy

\section{INTRODUCTION}

As the economics develops and globalization accelerates in China, eastern ports like Shanghai, Tianjin and Guangzhou has witnessed fierce competition from both home and abroad. To overcome this, researches have been conducted to analyze and optimized the logistic strategy for the coastal cities in China [1-3], and these researches are mainly conducted through the SWOT analysis [4]. However, it often lacked of quantitative analysis in SWOT analysis, so few was involved in the quantitative studies of logistic strategy. To acquire more precise information in decision making for the logistic strategy, it is of great necessity to make the analysis in both qualitative and quantitative manner for a specific coastal city, which will facilitate the logistic decision-making and promote the prosperity of a port.

In this paper, the typical port city Guangzhou was chosen to conduct the research. By cooperating the SWOT method and analytic hierarchy process, a framework model was constituted to analyze the logistic strategy in both qualitative and quantitative ways, and the optimized logistic strategy was finally revealed.

\section{MODEL CONSTITUTION}

The SWOT analysis was proposed by Kenneth R. Andrews in his book named Concepts for the Firm Strategy in 1971. It is one of the frequently-used methods in competition information analysis [5]. The SWOT analysis is to comprehend and summarize the external and internal factors in a specific enterprise or problem, and making the analysis of its strengths, weakness, opportunities and Threats. Then the effective and reasonable configuration was found to make the best option.

The analytic hierarchy process (AHP) was advocated by the American operational expert Satty, which converts the complex qualitative problems to be quantitative, and make the consistency check to people' decision making. Its major steps could be referred in literature [6]:

By cooperating the AHP and SWOT, complex problems will be clearer, organized, and the quantitative analysis will be very beneficial to find the key of a specific problem.

The technology route for constituting a framework model cooperating SWOT and AHP are listed as following:

(1) After literature review and research, the Factors of logistic strategy are divided into four Groups, that is strength (S), weaknesses (W), opportunity (O), and Threat (T).

(2) Second step: set the logistic strategy as overall objective, and choose strength $(\mathrm{S})$, weaknesses $(\mathrm{W})$,opportunity $(\mathrm{O})$, and threat $(\mathrm{T})$ as the systematic layer, and select the elements from that four groups to be the indicator layer, thus a hierarchical model for logistic strategy are established.

(3) Third step: assess the elements' importance in every level based on the expert's score, and establish the judge matrix of A, $\mathrm{S}, \mathrm{W}, \mathrm{O}, \mathrm{T}$ based on the assessment.

(4) Forth step: acquire the priority of the elements in every layer after the layer sorting and consistency check, this process includes two steps $[7,8]$ :

(1) Single layer sorting. It means the priority of all elements in a specific layer to its connected upper layer is to be calculated based on the constituted judge matrix. To ensure the reasonability of the hierarchy analysis results, the consistency of the judge matrix should also be checked. Here the negative 
average Eigen values (exclusive of the maximum Eigen values) was defined as:

$$
C I=\frac{\lambda_{\max }-n}{n-1}
$$

where, $\mathrm{CI}$ is the negative average Eigen values; $\lambda_{\max }$ is the maximum Eigen value of the judge matrix; $\mathrm{n}$ is the dimension of the judge matrix. When $\mathrm{CI}$ is zero, it means the judge matrix has the total consistency, and then the check process will end. When $\mathrm{CI}$ is not zero, we need to check the random consistency ratio $(\mathrm{CR})$, it was defined as:

$$
C R=\frac{C I}{R I}
$$

where, $\mathrm{RI}$ is the average random consistency index in judge matrix, and its values were listed in Table I.

TABLE I. AVERAGE RANDOM CONSISTENCY INDEX RI.

\begin{tabular}{cccccccccc}
\hline $\begin{array}{c}\text { Matrix } \\
\text { order }\end{array}$ & 1 & 2 & 3 & 4 & 5 & 6 & 7 & 8 & 9 \\
\hline RI & 0 & 0 & 0.58 & 0.90 & 1.12 & 1.24 & 1.32 & 1.41 & 1.45 \\
\hline
\end{tabular}

(2)Total layer sorting. It means the priority of all elements in target layer should be calculated based on the single-layer-sorting results in same layer and the priorities of all elements in upper layers. The total layer sorting consistency ratio (TCR) was defined as:

$$
T C R=\frac{a_{1} C I_{1}+a_{2} C I_{2}+\cdots a_{n} C I_{n}}{a_{1} R I_{1}+a_{2} R I_{2}+\cdots a_{n} R I_{n}}
$$

where, $a_{n}$ is the priority of the n-element in upper layer; and the results of the total layer sorting is reasonable when the TCR is smaller than 0.1 .

(5) Select the type of logistic strategy based on the professor Wang's procedure as follow [9]: (1) A four-half-dimensional Coordinate system was established by using $\mathrm{S}, \mathrm{W}, \mathrm{O}$, and $\mathrm{T}$ as one half dimensions respectively; and the element with the biggest priority during total-layer-sorting in each group was labeled in the axis of the coordinate system. A new strategic quadrilateral S1O1W1T1 was acquired by drawing a new line between the four elements, it was shown in Figs. 2. (2) Find the focus point $\mathrm{P}$ of the quadrilateral S1O1W1T1, and $\mathrm{P}$ is the comprehensive result of these four factors of $\mathrm{S}, \mathrm{W}, \mathrm{O}$ and $\mathrm{T}$, which is also the basis for strategy selection. The strategy is selected according to the focus point $\mathrm{P}$; its calculation equation is:

$$
X=\sum \frac{x_{i}}{4}
$$

$$
Y=\sum \frac{y_{i}}{4}
$$

where, $\mathrm{i}=\mathrm{S}_{1}, \mathrm{O}_{1}, \mathrm{~W}_{1}, \mathrm{~T}_{1}$; and the focus point $\mathrm{P}$ of the quadrilateral $\mathrm{S}_{1} \mathrm{O}_{1} \mathrm{~W}_{1} \mathrm{~T}_{1}$ means a logistic strategy. The corresponding relationship between the two is demonstrated in Fig. 1.

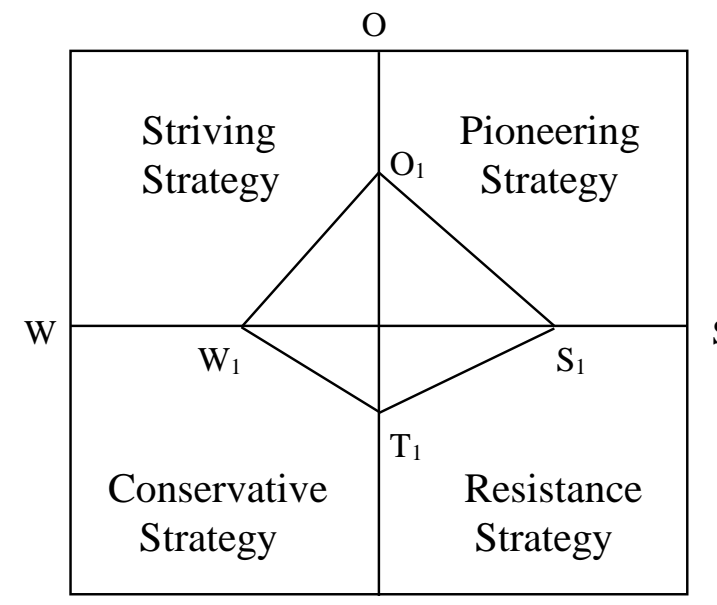

$\mathrm{T}$

Fig. 1. Strategy quadrilateral and its application.

\section{SWOT ANALYSIS OF LOGISTIC DEVELOPMENT IN GUANGZHOU PORT}

\section{A. Strengths}

Strong development potential: The economic hinterland of Guangzhou is given priority to Guangzhou, the Pearl River delta and other areas of Guangdong province, Hunan, Jiangxi, Guangxi, Yunnan, Guizhou and Sichuan, which was so called extended Pearl River delta region as indicated in Fig. 2.

This hinterland has a total area of about $200 \mathrm{~km}^{2}$, which accounts for one fifth of the national land area of China. And the economic strength is very strong with one third of the country's gross domestic product (GDP).

Superior geographic location: Guangzhou is the transportation hub in southern China. It has well-developed waterways, rail, road and air traffic, which has formed a convergence shot in Southeast Asia, connecting around the world by land, sea and air transportation network. Especially, Guangzhou is located in the Pearl River delta and its shipping resources are superior, it is very convenience to sail in the river and the sea directly, so it is well connected to Hong Kong and Macao. At present, the navigation water depth has deepened to - 
15. $5 \mathrm{~m}$ from the Pearl River mouth to the Nansha port area of Guangzhou port, the huge ship up to 100000 t can enter the city when the tide is rising. The Nansha port zone of Guangzhou is located in the hinterland of the Pearl River delta economic center, and it is the only deep-water wharf in the Pearl River west bank. Compare to other port in the pearl river delta, Nansha port area is closer to Guangzhou and the pearl river west cities like Foshan, Shunde, Zhongshan, Jiangmen, Zhaoqing, Huizhou and Dongguan city. It can be in only $1 \sim 2$ hours to deliver the goods between these neighbor cities between Guangzhou port.

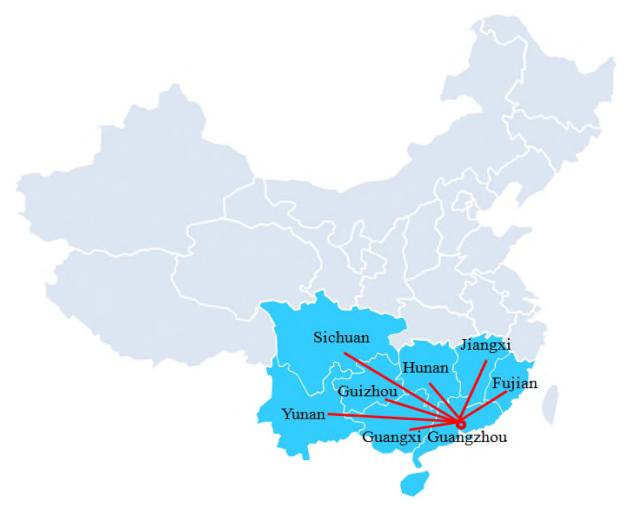

(1) hinterland area

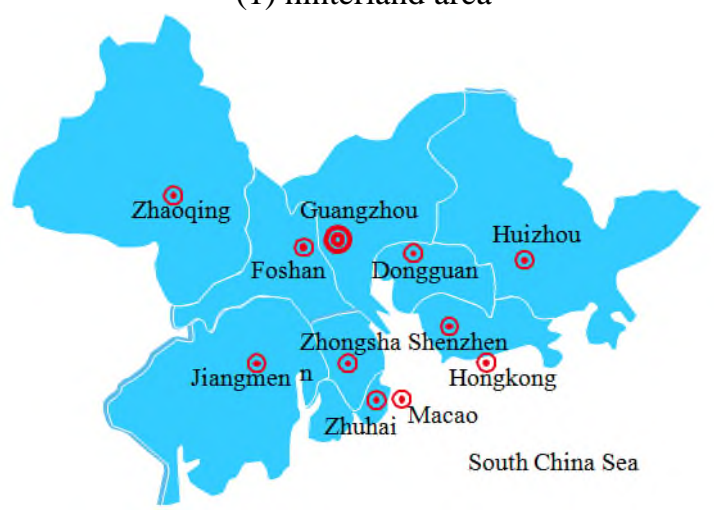

(2) geographic location

Fig. 2. The hinterland area and geographic location of Guangzhou port.

Prominent service function: The Guangzhou port is composed by inner port, Xinsha, Nansha and Huangpu harbor zone and anchorage at Pearl River's mouth. It has a group of advanced facilities of large container, coal, grain, oil and chemical industry, such as specialized deep-water wharf, and especially the largest Ro-ro terminal in southern China. Up to now, Guangzhou has all kinds of production berths up to 489 with s 88anchorage, including 58 large berths. The largest capacity can reach 300 thousand tons. There are 5 port railway named Beijing-Guangzhou, Beijing-Kowloon, Guang-Shen, Guang-Zhan, and Guang-Mei connecting Guangzhou to other cities. Guangzhou also has convenient highway which connects by urban rapid road, highway and national road. Among them, the Nansha express is directly leading to the Nansha port. In October 2008, the area of Nansha Bonded Port with its planning was $7.06 \mathrm{~km}^{2}$ and established in Guangzhou port, which marked the port has the highest level the most complete open policy and the most favorable areas under special customs supervision.

\section{B. Weaknesses}

Poor natural condition: Although the navigation water depth has deepened up to $15.5 \mathrm{~m}$, the ship of 100 thousand tons can go in and out from the pearl river mouth to the Nansha port area of Guangzhou port by tide; the Guangzhou port have to face the congenital advantage of the Hong Kong and Shenzhen; for the berth of Hong Kong has reached more than $20 \mathrm{~m}$ in depth, and its channel conditions is very good; and the main port of Shenzhen also has also a deeper berth with a coastline up to 20 $\mathrm{km}$. As the ship's large-scale trend has become increasingly apparent, the port and channel depth conditions demand is higher and higher, the natural conditions of is Guangzhou port the bottleneck of restricting its development [10].

Logistics development lag: For a long time, Guangzhou has not put enough importance to logistics industry development. Hong Kong has become a logistics center and international shipping center of Asian countries with the location advantage and the branding for many years; and logistics industry in Shenzhen also developed earlier than Guangzhou. It was not until 2003 had Guangzhou issued a plan for modern logistics development.

Imperfect supporting facilities: For Guangzhou port coastline covers multiple and relatively scattered administrative region area, the transport, banks, shops, restaurants, hotels and other basic living facilities cannot form scale effect in Guangzhou port. Moreover, the customs declaration, trailer, ship, freight forwarders and other related needs to be improved, and port shipping market remains to be integrated. In terms of customs clearance environment, Shenzhen port customs clearance is full time for $24 \mathrm{~h}$, Guangzhou is only $8 \mathrm{~h}$ a day for work week.

\section{Opportunities}

National policy support: In 2006, the ministry of communication issued the National Coastal Port Development Planning, establishment of Guangzhou as one of the key ports in the pearl river delta region of coal discharge and transportation system, container transport system, imports of oil and gas transfer storage and transportation system, discharge system of imported iron ore transporting via, food storage and transportation system, automobile transport system [11]. The State Council of China in 2008 passed the Reform and Development of the Pearl River Delta Area Plan, which aimed to promote Guangzhou port's construction of modern logistics park. And in 2009, the State Council released the Logistics Industry Adjust and Revitalization Plan, stating Guangzhou to become a national logistics node. All these policies and requirements are pointed out the development direction of the Guangzhou port logistics, and they also provide new opportunities.

Hinterland economic development: Since China's reform and opening up, the economy of Guangdong province has witnessed sustained and rapid development, and Guangdong 
has accumulated abundant material base and become the fastest economy growing province in China. And it is also one of the most developed areas with export-oriented economy. In 2008, the speed of economic development at home and abroad was obviously slow down due to the effect of financial crisis, But Guangdong and the Pearl River Delta region economy still maintained a good momentum of development in economy. Compared to 2007, the GDP in the Pearl River Delta region's in 2008 grown by $12.6 \%$ with an amount reached 29,745 . 745RMB. And the GDP grew by $10.1 \%$ and its sum reached 35 , 696.46 billion RMB in Guangdong province. With the industrial upgrading of Guangdong province, and the industrial structure and layout optimization, along with the advancement of pan-pearl river delta regional economic cooperation, hinterland economy will develop steady, and can provide a rich source of Guangzhou port [12].

Logistics development efforts: In recent years, Guangzhou has promulgated and implemented a series of logistics development planning, such as the Plan for Modern Logistics Development of Guangzhou in 2003, Logistics Park Development Plan of Guangzhou in 2004, and the Logistics Park Planning Control of Guangzhou in 2005, the Modern Logistics Development Planning of Guangzhou in 2006. In order to speed up in Guangzhou City's leading industry of modern service industry development, Guangzhou has released the Development of Modern Service Industry in Guangzhou 11th five-year planning in 2006, among which the logistics industry is defined as one of the important fields of modern service industry.

\section{Threats}

The Pearl River delta port group has formed into world-class scale, which has more than 60 ports. And the port berth is relatively concentrated in the same geographical position; the competition among them is particularly fierce [13].

Strength opponent-Hong Kong: Hong Kong is the world's seventh largest shipping center, as a deep water port and container port to the world's level, it is a major hub port on the global supply chain, and has about several dozen countries International shipping companies, and it provide more than 500 weekly container ships shift from more than 600 destinations around the world. Hong Kong port infrastructure is complete, and its traffic information, transportation, logistics are well developed, and the international transit capacity is particularly outstanding.

Rising star-Shenzhen: Shenzhen also have innate condition itself. Shenzhen port consists of two big port including Yantian and Sekou. Yantian port is deep water port, and it can easily let the international large ocean ships enter and leave. Moreover, Shenzhen is now developing hinterland, Yantian international container terminal will be the iron transport business from coastal to inland areas and in 18 October of 2008, Shenzhen got the formal approval from the State Council for the Bay Bonded Port Area, which provided a new platform for logistics development in Shenzhen.
Potential competitor-Zhuhai: Gaolan port of Zhuhai is a 50000 tons container terminal, it was put into trial operation in December 2008, which ended the history of no large international container in the west band of the Pearl River .Phase two of Gaolan port project completed the second 50000 tons container terminal in July 2009 Up to now Gaolan port has been built 32 production berths, of which 12 berths, level with the pearl river delta region's largest 80000 tons liquid chemicals port and 80000 tons oil products. The cargo throughput of Zhuhai Gaolan port will reach 100 million, and Zhuhai is going to build the international ocean-going main port of transformation by speeding up 4100000 DWT container port construction.

\section{ANALYSIS COMBINING SWOT AND AHP}

For further analysis, the strength, weakness, opportunity and Threat was chosen as the systematic layer, and the qualitative factors discussion above was selected as the index layer, then the annalistic framework for Guangzhou port was constituted as Figs. 3.

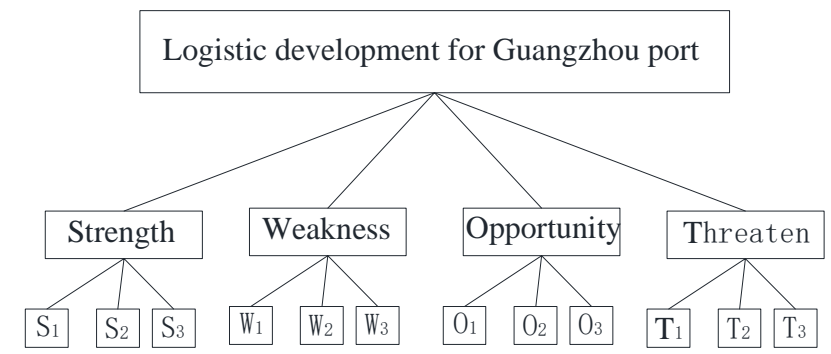

Fig. 3. Analytic hierarchy model of logistic development of Guangzhou port.

Through inquiring the experts in logistic field, communicating with the authority and making the questioner, the judge matrixes for Guangzhou port logistic development were listed as Table II.

TABLE II. JUdGMENT MATRIX A FOR GUANGZHOU LOGISTIC DEVELOPMENT.

\begin{tabular}{ccccc}
\hline A & Strength & Weakness & Opportunity & Threat \\
\hline Strength & 1 & 1 & 3 & $1 / 3$ \\
Weakness & 1 & 1 & 3 & $1 / 3$ \\
Opportunity & $1 / 3$ & $1 / 3$ & 1 & $1 / 7$ \\
Threat & 3 & 3 & 7 & 1
\end{tabular}

Based on the matrixes above, the factors 'priorities were calculated and check by the consistency principle. The results were listed in Table 3.

From Table III, it was found that all the judgment matrixes could past the consistence check; and the most important factors in each matrix was superior geographic location, poor natural condition, hinterland economic development and strength opponent separately. The total arrangement was acquired and was listed in Table IV. 
TABLE III. HIERARCHICAL SINGLE ARRANGEMENT AND CONSISTENCY CHECK.

\begin{tabular}{c|c|c|c|c}
\hline $\begin{array}{c}\text { Matrix } \\
\text { Value }\end{array}$ & $\mathrm{S}$ & $\mathrm{W}$ & $\mathrm{O}$ & $\mathrm{T}$ \\
\hline$\lambda_{\max }$ & 3.0613 & 3.0285 & 3.0235 & 3.0036 \\
\hline $\mathrm{CI}$ & 0.0325 & 0.0145 & 0.0124 & 0.0019 \\
\hline $\mathrm{RI}$ & 0.58 & 0.57 & 0.59 & 0.58 \\
\hline $\mathrm{CR}$ & 0.0559 & 0.0171 & 0.0212 & 0.032 \\
\hline $\begin{array}{c}\text { Normalized } \\
\text { Feature vector }\end{array}$ & $\begin{array}{c}0.7306, \\
0.1884)\end{array}$ & $\begin{array}{c}0.0704, \\
0.1782)\end{array}$ & $\begin{array}{c}0.6833, \\
0.1168)\end{array}$ & $\begin{array}{c}0.2297, \\
0.1220)\end{array}$ \\
\hline
\end{tabular}

TABLE IV. HIERARCHICAL TOTAL ARRANGEMENT AND CONSISTENCY CHECK.

\begin{tabular}{cccccc}
\hline Factor & $\mathrm{S}$ & $\mathrm{W}$ & $\mathrm{O}$ & $\mathrm{T}$ & $\mathrm{CR}$ \\
\hline Factor 1 & 0.0156 & 0.1451 & 0.0137 & 0.3533 & \\
Factor 2 & 0.1410 & 0.0136 & 0.0469 & 0.1252 & 0.0203 \\
Factor 3 & 0.0364 & 0.0344 & 0.0080 & 0.0665 & \\
\hline
\end{tabular}

It was indicated in Table IV that the total arrangement could also pass the consistency check. And it showed that the results could reflect the priority of all factors of Guangzhou logistical strategy. The poor natural condition in weakness was the most important among all factors of this research.

The factors of $\mathrm{S}, \mathrm{W}, \mathrm{O}$ and $\mathrm{T}$ were listed as semi axis and the four and a half $\mathrm{d}$ coordinate system was build. And the largest factor in the $\mathrm{S}, \mathrm{W}, \mathrm{O}$ and $\mathrm{T}$ serial was labeled in the correspondence semi axis. The strategy quadrilateral $\mathrm{S}_{1} \mathrm{~W}_{1} \mathrm{O}_{1} \mathrm{~T}_{1}$ was obtained. Then the weigh center of the quadrilateral $\mathrm{S}_{1} \mathrm{~W}_{1} \mathrm{O}_{1} \mathrm{~T}_{1}$ was found based on the fourth equation. According to Fig. 2, it was found that the option of logistical strategy in Guangzhou port should be conservative, which means the advantages of Guangzhou port was smaller than the disadvantages, and its development should overcome more difficulties.

\section{CONCLUSIONS}

Through cooperate the SWOT method and analytic hierarchy process, a framework model was constituted to make the analysis in both qualitative and quantitative ways. The typical port city, Guangzhou of Guangdong province in China, was chosen to conduct the logistic strategy research combining the SWOT method and analytic hierarchy process. And the optimized logistic strategy was finally revealed. The option of logistical strategy in Guangzhou port should be conservative, which means the advantages of Guangzhou port was smaller than the disadvantages, and its development should overcome more difficulties.

\section{REFERENCES}

[1] Y.L. Xu, "Status Quo and Development of Shanghai logistics industry", China Port, vol. 29, pp. 26-29, 2015.(in Chinese)
[2] H. Ye, "Shanghai port logistics development analysis and strategy selection", Logistical Technol. vol. 5, pp. 36-39, 2011.

[3] J.M. Wang, Development Strategy of Tianjin Port Logistics Development Co., Ltd, Master Dissertation of Tianjin University, 2010

[4] H. Terry, W. Roy, "The strategic development of manufacturing: market analysis for investment priorities", Euro. Manag. J. vol. 15, no. 3, pp. 297-302, 1997

[5] L.J. Peng, X.X. Wang, Y. Deng etc. "SWOT analysis method and its application in the case of competitive intelligence research", Intell. Mag. vol. 7, pp. 15-17, 2014

[6] Z.F. Li, “Analysis of China's strategy on arctic route”, China Soft Sci. vol. 1, pp. 1-7, 2014.

[7] J.Q. Cheng, Urban System Engineering, Wuhan University Press, Wuhan, Hubei Province of P.R. China, 2010.

[8] L. Yu, W.J. Yi, "Analytic hierarchy process application in the urban ecological environmental quality assessment”, Sichuan Environ. vol. 21, pp. 8-40, 2014.

[9] B.G. Wang, J.S. Gan, "SWOT analysis model of marketing strategy", Syst. Eng. Theor. Pract. vol. 12, pp. 34-41, 2017.

[10] D.Q. Yuan, Logistics Marketing, Mechanical Industry Press, Beijing, 2012.

[11] J. Cheng, Y.Q. Yuan, "The Pearl River delta port group of how to win in the competition", Enterp. Manag. vol. 23, pp. 11-13, 2008.

[12] B.C. Sun, "Guangzhou Nansha port area foreign trade container transport development and prospects", China Port. vol. 11, pp. 20-26, 2016.

[13] S.F. Diao, "Guangzhou port group container transport development strategy study”, J. Contain. vol. 7, pp. 18-21, 2013. 